\title{
Book Review: Eben Kirksey's Multispecies Salon
}

\author{
Reviewed by Vera Schoepe
}

\begin{abstract}
Vera Schoepe is a hybrid multimedia artist, teacher, and budding multimodality researcher in the Curriculum and Instruction Department at the University of Texas at Austin. She holds a master's with honours from École Nationale Supérieure de la Photographie in Arles, France, and has produced multimedia installations and directed intercultural workshops for children and youth internationally. In her pedagogical and artistic practice, she uses photography and other art media to document questions of memory, identity, and borderland territories, with emphasis on hybrid communities' enduring environmental challenges. Her multimedia cartographies are created in conversation with locals through interviews, oral history recording, and writing and art workshops. With her teaching, she seeks to explore the poetry and politics of shifting hybrid identities in public and private spaces and, ultimately, encourage young students to assert and cocreate their bearings in an ever-changing set of world variables. Email: veraschoepe@gmail.com
\end{abstract}

\section{Thinking/Playing/Living With Other Species: Unsettling the Western Ontological Status Quo}

Multispecies Salon presents a body of transdisciplinary inquiry that disrupts the Western academic status quo and blurs the seemingly fixed human/natural interactions in the context of posthuman-era research. Anthropologist Eben Kirksey edits a compilation of essays that document a series of emerging multispecies encounters that openly reject apocalyptic ideologies and revindicate biocultural hope in blasted landscapes. This flourishing multimedia project, which includes a companion website (www.multispecies-salon.org/), brings together conferences, exhibitions, environmental activist parades, art performances, and thought-provoking multispecies ethnographies. These hybrid practices span from San Francisco to New Orleans, New York City, and beyond. They also blur ontological categories and center the study of emerging multispecies encounters in the context of dystopian ruins affected by metastasized neoliberal capitalist policies. Attending to entanglements of subject and object, nature and culture, human and nonhuman, this audacious group of researchers unsettles normative research practices and replaces them with hybrid and experimental strategies.

The book includes essays by a myriad of creative agents, including multispecies ethnographers, artists turned biological scientists, and environmental activists, who all conduct critical research and cocreate provocative experiential projects. All project participants transgress ontological categories and explore new avenues of collaborative research, while "illuminating the workings of capital and power, nature and culture," as Kirksey writes $(2014$, p. 7). They write, morph, explore, make art, discuss what happens within and without their bodies, neighbourhoods, and regions. They "poach" theories by bringing together cultural and scientific research, weaving stories, and building art manifestations. These subversive researchers become-with germs, nonhuman beings, and the ecosystems they share. Generative and hopeful interruptions might seem hidden within the work, but they are ever present. For example, Jacqueline Bishop's work Trespass contains latent seeds of biocultural hope, such as seed pods, mushrooms, and bird eggs, all cleverly hidden in detritus soil seemingly drowned in oil. Months before Hurricane Katrina in 2005, Bishop created a series of assemblage pieces using artificial birds, baby shoes, bird nests, and toys "coated in a black patina, a dark, glossy finish like crude oil" (Kirksey, 2014, p. 31). The dark shapes lay entangled and dormant on strands of hay, creating an unexpected network of scavenged waste. Light colourful markings depicting seed pods, leaves, bird eggs, flowers, fruits, and mushrooms emerge from dark iridescent shapes that prefigure the overwash of Hurricane Katrina and the BP oil flood in the Gulf of Mexico. Such seemingly hidden traces speckle gleanings with latent organic hope.

The book is divided into three sections: "Blasted Landscapes"; "Edible Companions"; and "Life and Biotechnology." The sections cover exterior multispecies interactions, inner comminglings, and biotechnological happenings. 
Across sections, each project offers unique and provocative approaches for engaging in multispecies encounters and hybrid experiences that creatively respond to anthropogenic landscapes. In the first section, Ro Mayer creates a custom parade to speak for the rights of animals and mourn the 2010 oil spill in the Gulf of Mexico; Elizabeth Acevedo resituates herself in a recovered landscape and documents her dystopian wanderings through photography; Karin Bolender undertakes a walking journey with a donkey, then after the donkey gives birth, traces the pollution that the donkey has been exposed to across multiple landscapes by containing it in donkey milk soap; and Anna L. Tsing documents the persistent flourishing of Matsutake mushrooms in contaminated or torn-up landscapes. In the second section, Myrtle von Damitz III depicts humans as paella bites; Heather Paxson further disturbs antiseptic peace with her germ questioning; Miriam Simun stories microbe-human collaborations by making human cheese; Lindsay Kelley makes Plumpiñon-a play on a branded form of food aid, to bring attention to the entanglements of food and global neocolonial and neoliberal hegemonies; Indigenous Pomo Elders of northern California discuss recipes and varying degrees of bitterness and share how making acorn mush is a form of connection to oaks, places, memories, and traditions; and Caitlin Berrigan sets up a symbiotic transfusion of fluids between humans and dandelions as an exchange of nutrients that simultaneously gestures to multispecies reciprocity while unsettling regulatory approaches to human-microbe relations. In the third section, Andre Brodyk paints with Alzheimer's disease bacteria; Praba Pilar questions the god of biotechnology; Karen Barad explores how "brittlestars challenge disembodied epistemologies and traditional notions of embodiment" (Kirksey, 2014, p. 228); and Patricia Piccinini sculpts toy-size stem cells and turns them into playful, disturbing critters that complexify biotech-onto-ethical boundaries. These hybrid practices are uniquely messy and unsettling. However, the researchers succeed in cocreating unexpected hope by dispelling purely anthropogenic interferences, engaging in reciprocal gestures and lingering in (dis)comfort.

Tsing (2012), in her project Unruly Edges, proclaims that "human nature is an interspecies relationship" that replicates symbiotic ties within and without human bodies and ecosystems (p. 144). The vibrant transdisciplinary approach embedded in the project takes myriad multifaceted shapes at the "fingereyes" of ethnographers, artists, and other living organisms, making them entangled kin (Kirksey, 2014, p. 14). It encourages a multiplicity of multispecies comminglings, all emerging from novel experiences and seemingly posthuman vanguard encounters; it sets loose parasites and encourages frenetic germinations with no specific outcome. By gathering a growing archive of observations, experiments, recipes, and ethnographic vignettes, the project gleans/trespasses, making use of excess (Kirksey, 2014, p. 17). As Bolender claims in her project, by the time we finish reading the book and immerse ourselves in the companion multimedia website, we are "in the meshes of otherness where we find ourselves" (quoted in Kirksey, 2014, p. 83).

This piece of collaborative transdisciplinary research aims to (de)center and question human presence in dystopian ruins in late capitalism. It seeks to unsettle preconceptions of human domination and engages in collaborative research that avidly grafts a multitude of voices that think, play, and commingle with other species in a rampant crescendo of willingly tainted collaborations. It investigates the question "Which beings flourish, and which fail, when natural and cultural worlds intermingle and collide?" (Broglio, 2011, p. xvii). Far from surrendering to manmade disaster, the Multispecies Salon researchers revindicate active roles as agents, tinkerers, collaborators, and creators of experience. They seek to disrupt the perceived hierarchy of human-natural order. The book's contributors document shifting multispecies relations and puncture anthropocentric ontological theories; they systematically seek to unsettle the human element. However, rather than weave an apocalyptic tale or sing a posthuman requiem, the researchers choose to join the human mess and enter in playful conversation with human and nonhuman others. Throughout the project, "[the noise of becoming] invades and occupies" (Serres, 2007, p. 253); it hybridizes the experiential inquiry of all agents involved, regardless of their species or condition. 
The projects outlined within the book require the viewer to dig deeper and look beyond toxic surfaces or seemingly apocalyptic circumstances. Engaging in emerging collaborations, the researchers seek to enter into open conversation with other species, thus subverting expected outcomes and pushing for unpredictable results. They sublimate obstacles and transform them into opportunities, thus overflowing oil spill sites, dry lands, sick bodies, and postcatastrophic urban wastelands become places for ingenious embodied responses. Priming a multitude of voices, this multimedia project that is the Multispecies Salon challenges the academic status quo by repositioning nonhuman entanglements in the context of the Anthropocene era (Kirksey, 2014, p. 4). By digging deep and beyond the commonly adopted Western binary system, the book encourages the use of hybrid practices that experiment with multispecies becoming. This cathartic piece of literature seeks to activate the conjoined work of social researchers, educators, and artists through these very practices. In this collaborative research initiative, Kirksey and company call on humans to refuse to engage in defeatist apocalyptic conclusions. They encourage play and the cocreation of new reciprocal relationships with nonhuman beings, and in hopes of rebirthing ideas and practices that defy both extinction and human exceptionalism. The projects within the book furthermore redefine the role of ethnography as a discipline and invite the reader to participate in the poaching of emerging theories and practices, as well as the reweaving of shared experiences. Donna Haraway echoes Bruno Latour when she affirms that "who and whatever we are, we need to make-with-become-with, compose-with-the earth-bound ... we are all compost" (2015, p. 161). Ultimately, the Multispecies Salon proposes a new sense of aesthetics that seeks to comingle, question, and live with less beautiful beings such as viruses, often-ignored animals, and ever-quiet plants, thus inciting unsettling multispecies encounters that persistently challenge and subvert the Euro-American ontological canon.

The contributors embrace uncomfortable multispecies encounters in order to breach openings that provoke dialogue, action, subversion, and awareness. They choose to create and document uncontrolled becomings to disrupt seemingly barren human ruins. Their aim is to awaken a highly disengaged audience that suffers from a postmodern state of anxiety and fear. The work by Kirksey et al. reads as a becoming text that seeks to infect humans with resourceful multispecies tactics that critically examine and change future worlds. Moreover, the project provokes a creative awakening that refuses to surrender to pervasive neoliberal tendencies in the domains of science, art, and cultural research, which directly affect education. The Multispecies Salon defends the need for symbiotic cooperation across species, thus promoting the cocreation of a new "compost-ist" order that is rooted in complex entanglements with animals, ecosystems, and technology through critical, cathartic, hybrid actions (Haraway, 2015, p. 161).

In the light of multispecies ethnographic research, I am intrigued by the notions of using "more-than-human geographies" in the classroom, as mentioned by Thom van Dooren et al. (2016) in Cultivating Arts of Attentiveness. The work of van Dooren and his colleagues echoes the many thought projects in the Multispecies Salon in that both profess a joint interest in "better understanding what is at stake-ethically, politically, epistemologicallyfor different forms of life caught up in diverse relationships of knowing and living together" (van Dooren et al., 2016, p. 5). I join van Dooren et al. in their advocacy of a "passionate immersion" (2016, p. 6). I want to pose these questions to parents, students, and fellow teacher-researchers: How can we be more present to emerging multispecies encounters and learn to become-with others inside and outside of our classrooms? How can we work across multispecies worldlings and pollinate our experience and understanding? (van Dooren et al., 2016, p. 17). How can we pay careful attention to what matters to others and craft "shared lives and worlds in multispecies communities" (van Dooren et al., 2016, p. 8)? In other words, how can we learn "to be affected" together (Despret, 2004, p. 131)?

Affrica Taylor and Miriam Giugni (2012) write that "learning how to world is the charter of our early childhood 
common worlds framework," which includes

how to be responsible in and for our common worlds; how to bring others into our common worlds; how to form 'questioning relationships' with these others; how to negotiate common interests in common worlds; and how to practice a relational ethics. (p. 117)

To become immersed in healthy commingled living and learning, it is necessary to become "curious and so entangled and so perhaps to understand and care a little differently" (van Dooren, 2014, p. 6). As I intimately develop my environmental education pedagogical practices, I realize, as van Dooren and colleagues (2016) write, that "life cannot arise and be sustained in isolation ... relationships also have histories" (p. 2). I question how to decenter my own presence as educator, artist, and human in order to witness/listen/participate/cocreate ongoing multispecies encounters where otherness can emerge. As van Dooren (2014) notes, "the specificity and proximity of connections matter" (p. 60).

While considering how to apply this groundbreaking multispecies research to environmental education, I would like to encourage my readers to consider these questions: How might children's learning journeys be supported in ways that are open to multispecies encounters and thus observations and experiences outside of constrained institutional settings? How can teachers and parents address anthropocentric colonial tendencies when teaching environmental science in myriad settings? To what extent can teachers adjust pedagogical strategies to include multispecies encounters in multiple geographic foci? What different kinds of pedagogical tools and strategies might be needed to do this? Furthermore, is it possible for environmental educators to promote care for the natural world through pedagogical multispecies encounters without falling prey to preconceived human-centered conclusions? Last, to what extent can environmental science educators disrupt "eco-edutainment" solutions and provoke meaningful student engagement that is critical of pervasive colonial human-centered legacies?

It is a good start to admit grossly human-centered inclinations when teaching environmental science. By engaging with more-than-human beings, educators can cocreate authentic learning and becoming through multispecies encounters. I strongly believe that environmental science educators need to "stay with the trouble" as Haraway (2016) recommends. She further writes, "It matters which stories tell stories, which concepts think concepts" (2015, p. 160). If educators are going to provoke, support, and facilitate learning experiences with nature, why not take inspiration from these multispecies projects in seeking different ways to respond, play, create, and attune to more-than-human others and our shared habitats?

When rethinking animal-focused environmental science education, we might consider what Teresa Lloro-Bidart and Constance Russell (2017) remind us: Environmental education

pedagogies that rely on the one-way transmission of depoliticized facts are problematic. Critical environmental education research demonstrates, for example, that when teachers or interpreters explicitly engage the political aspects of environmental learning (such as policies guiding animal treatment), learners emerge with greater sense of responsibility for caring for other animals.... Further, the hidden curriculum in both cases contains anthropocentric elements that undermine stated conservation goals. As commodities packaged for our viewing pleasure ... there is very little attention to them as individual subjects of their own lives. (p. 6)

To make visible shared worlds that are woven with lively stories, we must learn how to enter into conversation with more-than-human companions. In learning environments, it is important to address hidden curricula and find ways to subvert neoliberal colonial agendas. As educators, we can seek possibilities for building interspecies networks where new connections flourish over an extended period of time. Only then can lessons inspired by 
the Multispecies Salon multimedia project germinate and displace human-centered thinking. By rejecting notions of human isolation and of self-sufficiency through extraction, exploitation, and consumerism, we embrace the "other" in ourselves and other species. When we choose to embrace the unknown and stay with the trouble, as Haraway (2016) explains, we begin to think, play, and inhabit shared spaces with others. Only then can we hope to finally blast the notion of a posthuman era through shared action, stories, and experiences that cocreate potentially life-changing relations across species. 


\section{References}

Broglio, R. (2011). Surface encounters: Thinking with animals and art. Minnesota Scholarship Online. Retrieved from https://doi. org/10.5749/minnesota/9780816672967.001.0001

Despret, V. (2004). The body we care for: Figures of anthropo-zoo-genesis. Body Society, 10(2-3), 111-134. doi: 10.1177/1357034X04042938

Haraway, D. (2015). Anthropocene, Capitalocene, Plantationocene, Chthulucene: Making kin. Environmental Humanities, 6(1), 159-165. doi: 10.1215/22011919-3615934

Haraway, D. J. (2016). Staying with the trouble: Makingkin in Chthulucene. Durham, NC: Duke University Press. doi: 10.1215/9780822373780

Kirksey, E. (Ed.). (2014). The multispecies salon. Durham, NC: Duke University Press. doi: 10.1215/9780822376989

Lloro-Bidart, T., \& Russell, C. (2017). Learning science in aquariums and on whalewatching boats: The hidden curriculum of the deployment of other animals. Animals and Science Education: Ethics, Curriculum and Pedagogy, 2, 41-50. doi: 10.1007/978-3319-56375-6_4

Serres, M. (2007). The parasite. Minneapolis: University of Minnesota Press.

Taylor, A., \& Giugni M. (2012). Common worlds: Reconceptualising inclusion in early childhood communities. Contemporary Issues in Early Childhood, 13(2), 108-119. doi: 10.2304/ciec.2012.13.2.108

Tsing, A. L. (2012). Unruly edges: Mushrooms as companion species. For Donna Haraway. Environmental Humanities, 1(1), $141-154$. doi: $10.1215 / 22011919-3610012$

van Dooren, T. (2014). Flight ways: Life and loss at the edge of extinction. New York, NY: Columbia University Press.

van Dooren, T., Kirksey, E., \& Münster, U. (2016). Multispecies studies: Cultivating arts of attentiveness. Environmental Humanities, 8(1), 1-23. doi: $10.1215 / 22011919-3527695$ 